\begin{tabular}{|c|l|}
\hline Title & A physical study on the thermal ice ridge in a closed deep lake : Lake Kuttara, Hokkaido, Japan \\
\hline Author(s) & A ihara, Minoru; Chikita, Kazuhisa A .; Momoki, Y oshiro; Mabuchi, Suguru \\
\hline Citation & $\begin{array}{l}\text { Limnology, 11(2), 125-132 } \\
\text { https:/doi.org/10.1007/310201-009-0298-0 }\end{array}$ \\
\hline Issue Date & 2010 \\
\hline Doc URL & http://hdl.handle.net/2115/44619 \\
\hline Rights & The original publication is available at www.springerlink.com \\
\hline Type & article (author version) \\
\hline File Information & Aihara_Limnology 2009.pdf \\
\hline
\end{tabular}

Instructions for use 


\section{A physical study on the thermal ice ridge in a closed deep lake: Lake Kuttara, Hokkaido, Japan}

Minoru Aihara $^{1}$, Kazuhisa A. Chikita ${ }^{2}$, Yoshiro Momoki ${ }^{3}$ and Suguru Mabuchi ${ }^{4}$

1 INA Engineering, Inc., Tokyo, 112-8668, Japan

152 Faculty of Science, Hokkaido University, Sapporo, 060-0810, Japan

3 Senior High School of Yokote, Yokote, 013-0008, Japan

4 Central Civil Engineering Research, Inc., Utsunomiya, 321-0346, Japan 


\section{Abstract}

An ice-ridge line more than $2000 \mathrm{~m}$ long was found out in a closed, deep lake, Lake Kuttara, Hokkaido, Japan, in the ice-covered season of 1995. In order to clarify when and how the ice-ridge line built up, the meteorology and the ice and water temperatures were monitored, and the density, thermal conductivity and thickness of the covered ice were measured in January - March 1995. The covered ice on 4 and 5 March 1995, which correspond to the period with the thickest lake ice, consisted of snow ice 0.05 to $0.07 \mathrm{~m}$ thick and candle ice 0.18 to $0.21 \mathrm{~m}$ thick. Numerical simulations for the ice thickness and ice temperature were carried out by using a one-dimensional, unsteady three-layer model. The simulated results, which were reasonable to the observations, state that, due to the ice contraction and expansion, the ice-ridge line started to construct on 2 February and was completed on the next day.

Keywords Lake Kuttara, Ice ridge, thermal contraction, thermal expansion, Ice growth simulation

\section{Introduction}

below $4{ }^{\circ} \mathrm{C}$ in winter, generally experience the complete ice cover by early spring (Yoshimura 1937, Chikita et al. 1998). The phenomenon of the complete ice cover is probably important to the ecosystem in the lakes, especially in brackish lakes with the lower anoxic layer, because there are then the little oxygen input from the atmosphere and the small surface water input. Under condition of the complete ice cover, the vertical structure 
thickness could be important factors controlling the primary production below the ice. In a coastal lagoon, Lake Harutori, Hokkaido, Japan, Chikita et al. (1998) found out that, being independent of the structure and thickness of lake ice on the freshwater layer, the shortwave radiation at a water depth of $0.8 \mathrm{~m}$ becomes zero at the snow depth of more than $0.22 \mathrm{~m}$ on the ice.

the thermal contraction and subsequent expansion of ice or probably by wind-induced ice motions (URL: http://www.duluthstreams.org/understanding/iceRidges.html for Lake Superior and http://en.wikipedia/wiki/ Lake_Puma_Yumco for Lake Puma Yumco on the Tibetan Plateau). If the lakeshores are gently sloping, the expanding ice overrides them and shoves the shore materials, which forms the ice ramparts or ice ridges on the shores, if the shore materials are of a yielding sort. This phenomenon has often been given some damage to houses or facilities on the lakeshore for some lakes, Minnesota, USA (URL: http://www.dnr.state.mn.us/waters/watermgmt_section/pwpermits/ice_ridges.html). Thus, both the prediction of the thickness and motion of the covered ice and the investigation of the formation processes for the ice ramparts or ridges are important. In Japan, temperate lakes, Suwa and Kussharo, are known as lakes where ice-ridge lines are developed on the covered ice inward from the shoreline in winter (Yoshimura, 1937, Nakamura et al., 1998). Such ice-ridge lines are legendarily called "Omi-watari” (God's Crossing on Ice) in Japan. Rogers et al. (1995) developed a numerical model for predictions of the ice thickness and water temperature in a Canadian shallow lake. However, the Canadian lake has no ice ridge nor inverse thermal stratification in winter. A deep lake such as Lake Kuttara exhibits the stable thermal stratification below the covered ice in winter (Kozeki and Yoshida, 1972), and thus the upward thermal flux at the ice-water interface is considered to be nearly constant. However, 
the mechanisms of ice growth and ice-ridge formation in a deep lake are not yet enough investigated. Field observations and physical theories, focusing on how the covered ice grows and the ice-ridge lines build up, are still necessary. The formation of covered ice and subsequent addition of snow to the ice could affect the underwater ecosystem critically, as far as large variations of air temperature from winter to winter continue, being independent of global warming.

In this study, simulations for predictions of the thickness and temperature of covered ice in a deep lake are carried out, and by comparison with field observations, when and how the ice ridge built up is discussed.

\section{Study site and observations}

148m, which was formed ca. 40,000 years ago by an eruption of Kuttara Volcano (Fig. 1; Chikita et al. 1993, 1995, Boehrer et al. 2008). The lake (surface area, $4.7 \mathrm{~km}^{2}$ and water level, $258 \mathrm{~m}$ a.s.1.) is located at $5.2 \mathrm{~km}$ northwestward from the coast of the Pacific Ocean. The shoreline development, $S D$, defined by $S D=L /\left[2(\square A)^{1 / 2}\right]$ is 1.5 , thus indicating that the shape of the shoreline is close to a circle, where $L$ is the shoreline length (m), and $A$

15 is the water surface area $\left(\mathrm{m}^{2}\right)$. The lake is surrounded by the caldera wall ca. $250 \mathrm{~m}$ higher than the lake surface. Ishikawa et al. (1979) found out that the strong cooling by the longwave radiation occurs within the caldera wall in the ice-covered period. In the previous years before 1998, the lake becomes completely ice-covered in late January to mid-February, which continues until mid-April. The ice ridge is then built up at a similar location by early March at latest (personal communication with Ms. Naoko Mayeda, a curator of the Bear Museum at point K). 
An ice-ridge line more $2000 \mathrm{~m}$ long across the lake was seen at point $\mathrm{K}$ on 24 February 1995. For specifying the location and scale of the ice-ridge line and for measuring the snow depth, three observation lines from points F0 to F1200, from points MF600-1 to F600-2, and from points MF1200-3 to F1200-4 were set for 3 to 5 March 1995. The distance between the two neighboring points on the line of F0 to F1200 is $100 \mathrm{~m}$, and point 5 F1200 is located near the center of the lake. The accurate location of the ice-ridge line was determined by a theodolite (accuracy of horizontal distance, $\pm 0.05 \mathrm{~m}$ ) and the structure of the ice ridge was then examined in detail at point C on the line of points F1200 to MF1200-3 (126m north of point F1200). There were also many fractures making lines at the ice surface (Fig. 1), whose location was specified by the theodolite.

The ice cores were sampled at point F600 on 4 March and at points F2 and F1200 on 5 March. Immediately

10 after the sampling, the inner structure of the ice was specified, and the density was measured by hanging the cored ice into kerosene at a certain temperature. In advance, the relationship between the density, $\rho_{k}\left(\mathrm{~kg} \mathrm{~m}^{-3}\right)$, and temperature, $T_{k}\left({ }^{\circ} \mathrm{C}\right)$, for kerosene was linearly obtained by $\rho_{k}=-0.7 T_{k}+799.9$ (correlation coefficient, $r=0.997$ ) in laboratory. The interior temperature of covered ice was measured at $1 \mathrm{hr}$ intervals at depths of $0 \mathrm{~m}, 0.05 \mathrm{~m}, 0.1$ $\mathrm{m}$ and $0.15 \mathrm{~m}$ of point $\mathrm{F} 600$ for 3 to 5 March 1995 by using thermistor thermometers (accuracy, $\pm 0.05^{\circ} \mathrm{C}$ ).

15 Similarly, water temperature was measured at $0.1 \mathrm{~m}$ below the ice base. Air temperature was recorded at $1 \mathrm{hr}$ intervals in a ventilation shelter at $1.36 \mathrm{~m}$ above the snow surface (snow depth, $0.17 \mathrm{~m}$ ) of point $\mathrm{F} 600$.

On or around the lakeshore at point $\mathrm{M}$, the structural conditions of the covered ice were specified by a topographic survey, and lake water level was measured by opening the ice. The measurements were carried out on 24 March 1995. 
surface) on the shore for a period of 1 January to 10 March 1995. Meanwhile, the condition of the lake surface was daily viewed at point $\mathrm{K}$ (550m a.s.1.) by the curator of the Bear Museum. The precipitation data was obtained at a weather station $5 \mathrm{~km}$ south-southwest of the lake. The hourly data of wind speed, snowfall and actual daylight length were obtained at a weather station in Noboribetsu-city $6.4 \mathrm{~km}$ southwest of Lake Kuttara. The data of cloudiness and atmospheric vapor pressure were supplied from a weather station in Muroran-city $26.4 \mathrm{~km}$ southwest of the lake.

\section{Observational results and discussion}

Figure 2 shows temporal variations of daily maximum, minimum and mean air temperatures and daily precipitation (snowfall) for 1 January to 10 March 1995 . The air temperature abruptly decreased to below $-5{ }^{\circ} \mathrm{C}$ on 11 January but with open water, and then snowfall was recorded on 22 and 23 January with increasing air temperature. The precipitation of 23 January was $45 \mathrm{~mm}$, and this large snowfall caused the complete snow-ice cover at the lake surface on 24 January; this change at the lake surface was ascertained from a visual observation at point $\mathrm{K}$. At a first stage of the snowfall, the snow slush (mixture of snow and water) was probably made up at the lake surface, and then gradually froze into snow ice, since the atmospheric cooling at below $0{ }^{\circ} \mathrm{C}$ occurred on

24 January.

Figure 3 shows the inner structure of the cored ice sampled at points F2 and F1200 on 5 March and at point F600 on 4 March. A snow ice layer is 0.050 to $0.070 \mathrm{~m}$ thick, which was probably made up by the large snowfall on 23 January. Below the snow ice layer, there was a layer of transparent "candle ice" 0.178 to $0.210 \mathrm{~m}$ thick. The 
2). The mean snow depth along the line F0 - F1200 was $0.153 \mathrm{~m}$ on 3 March. The density, $907 \mathrm{~kg} \mathrm{~m}^{-3}$, of snow ice at point $\mathrm{F} 600$ was smaller than that of candle ice $\left(912\right.$ or $\left.921 \mathrm{~kg} \mathrm{~m}^{-3}\right)$. This is probably because the snow ice involves small air bubbles. The transparent candle ice had no bubbles, and thus appeared to be close to pure ice. In fact, the mean density, $917 \mathrm{~kg} \mathrm{~m}^{-3}$, is almost equal to the pure ice density, $916.4 \mathrm{~kg} \mathrm{~m}^{-3}$, at $0^{\circ} \mathrm{C}$. ridge was constructed $1.85 \mathrm{~m}$ long on the lake-ice surface and its top was $0.32 \mathrm{~m}$ higher than the lake-ice surface. The ice block, consisting of snow ice $0.04 \mathrm{~m}$ thick and candle ice $0.09 \mathrm{~m}$ thick, upthrust at the angle of $32.5^{\circ}$, and had a projected part of candle ice $0.02 \mathrm{~m}$ thick at the base. The structure of the ice block is thus similar to that of the lake ice in Figure 3. The snow depth around point $\mathrm{C}$ was $0.20 \mathrm{~m}$, and most of the ice ridge was snow-covered. The snow on the lake ice at or around point $\mathrm{C}$, which of the bottom part was the granular snow $0.03 \mathrm{~m}$ thick, was not wet at the interface between snow and ice. These suggest that the ice block was part of the lake ice before the upthrust, and that, on 5 March 1995 during the survey of the ice-ridge line by a theodolite, the upthrust had ceased. This situation is consistent with the discovery of the ice-ridge line at point $\mathrm{K}$ on 4 February. The ice-ridge line was formed probably by the ice contraction and expansion, due to the low air temperature and great daily variation of air temperature on 2 - 3 February (Fig. 2). At the lake ice surface near the ice ridge, four plates of clear ice, $0.02 \mathrm{~m}$ thick and $0.55 \mathrm{~m}$ long, clung to one another as the counterpart of the ice-ridge plate. The interior of the clear ice had no pillar-like joints as did the candle ice. This suggests that the thin clear-ice plates were simultaneously made up by a freeze at the open water surface and subsequent thrust after cracking.

There were many fractures making lines on the lake-ice surface (Fig. 1). Wet snow was found out around some of the fractures. This indicates that lake water oozed from below the lake ice through the fractures. 
Figure 5 shows structural conditions of covered-ice blocks on or near the lakeshore and associated water level at point M (Fig. 1). Five cracks on the covered ice, as shown by the arrows, were seen along the lakeshore, and two of them had steps $0.01 \mathrm{~m}$ or $0.03 \mathrm{~m}$ high. The water level at point $\mathrm{P}$ was at $0.22 \mathrm{~m}$ below the ice surface, while that at point $\mathrm{N}$ was at the ice surface. Nakao et al. (1967) reported that the water level in the ice-covered season decreases at $5.2 \mathrm{~mm} \mathrm{day}^{-1}$ by groundwater leakage. The covered ice farther from the lakeshore could be lowered, due to the decreasing water level, and finally produce such step-like cracks near the lakeshore by detachment. The water level before making the cracks should be $0.26 \mathrm{~m}$ higher than that on $24 \mathrm{March}$. Using the decline rate, $5.2 \mathrm{~mm} \mathrm{day}^{-1}$, the date of water level $0.26 \mathrm{~m}$ higher is estimated to be 2 February, when the covered ice would have dumped by $0.315 \mathrm{~m}$, detached at point $\mathrm{M}$, due to the contraction of ice mass under the rapid cooling on the day (Fig. 2). The covered ice was then fixed by the ice blocks on the shore, which is effective to suppress the horizontal movement of the covered ice by thermal expansion. The condition for constructing the ice ridge was thus prepared probably on or after 2 February.

Figure 6 shows time series of (a) wind speed and wind direction, (b) air temperature and (c) ice and water temperatures at point F600 for 3-5 March 1995. The lowest and second lowest air temperatures at point A in January to March 1995 were recorded on 4 and 5 May, respectively (Fig. 2). The daily minimums at point F600 were then $-21.8^{\circ} \mathrm{C}$ and $-25.2^{\circ} \mathrm{C}$ at $07: 00 \mathrm{~h}$ on 4 and $5 \mathrm{March}$, accompanied by the daily amplitude of more than $20^{\circ} \mathrm{C}$. The lowest temperature of the covered ice was $-2.3^{\circ} \mathrm{C}$ at the surface $(08: 00 \mathrm{~h}, 4 \mathrm{March})$, and $-2.1^{\circ} \mathrm{C}$ at 0.05m depth (09:00h, 4 March), whereas the ice temperatures at $0.1 \mathrm{~m}$ and $0.15 \mathrm{~m}$ depth were almost constant at $0^{\circ} \mathrm{C}$. These small variations mean that the snow layer $0.17 \mathrm{~m}$ thick above the ice surface acts enough as an insulator for the atmospheric cooling (Fig. 3). The ice surface temperature reached to $0^{\circ} \mathrm{C}$ at 23:00h, 4 March, and 
the temperatures at depths of $0.1 \mathrm{~m}$ and $0.15 \mathrm{~m}$ in the ice increased to $0^{\circ} \mathrm{C}$ at 20:00h and 22:00h, 3 March, respectively. This suggests that the lake water below the covered ice then oozed up to the ice surface through fractures.

\section{Numerical simulations for temperature and growth of lake ice}

Lake Kuttara probably started the ice cover on 23 January 1995 by forming the snow slush at the water surface, due to the large snowfall (Fig. 2). In order to specify when and how the ice-ridge line built up, the thickness and temperature of snow ice and candle ice after 23 January were numerically simulated by considering the heat budget at the snow surface and the insulated effect of overlying snow. Finally, the simulated results were compared with the observations at point F600.

Basic equations for the temperature simulation

The change of temperature, $T\left({ }^{\circ} \mathrm{C}\right)$, at a certain point within snow, snow ice or candle ice is

one-dimensionally shown by the following equation (Pivovarov, 1973):

$$
\frac{\partial T(z)}{\partial t}=\frac{1}{c \rho} \frac{\partial Q}{\partial z}
$$

where $Q$ is the heat flux $\left.(\mathrm{W} \mathrm{m})^{-2}\right)$ within snow, snow ice or candle ice, $c$ and $\rho$ is the specific heat $\left(\mathrm{J} \mathrm{kg}^{-1}{ }^{\circ} \mathrm{C}^{-1}\right)$ and density $\left(\mathrm{kg} \mathrm{m}^{-3}\right)$, respectively, of snow $\left(c_{s}\right.$ and $\left.\rho_{s}\right)$, snow ice $\left(c_{s i}\right.$ and $\left.\rho_{s i}\right)$ or candle ice $\left(c_{i}\right.$ and $\left.\rho_{i}\right), z$ is positive downward from the snow surface, and $t$ is the time. The heat flux, $Q$, is given as $Q_{s}, Q_{s i}$ and $Q_{i}$ for snow, snow ice and candle ice, respectively, by the following: 


$$
\begin{array}{ll}
Q_{s}=-k_{s} \frac{\partial T_{s}(z)}{\partial z}+(1-\alpha) R_{I} \cdot \exp \left(-\lambda_{s} z\right) & \left(0<z \leq h_{s}\right) \\
Q_{s i}=-k_{s i} \frac{\partial T_{s i}(z)}{\partial z}+(1-\alpha) R_{I} \cdot \exp \left\{-\lambda_{s} h_{s}-\lambda_{s i}\left(z-h_{s}\right)\right\} & \left(h_{s}<z \leq h_{s}+h_{s i}\right) \\
Q_{i}=-k_{i} \frac{\partial T_{i}(z)}{\partial z}+(1-\alpha) R_{I} \cdot \exp \left\{-\lambda_{s} h_{s}-\lambda_{s i} h_{s i}-\lambda_{i}\left(z-h_{s}-h_{s i}\right)\right\} & \left(h_{s}+h_{s i}<z \leq h_{s}+h_{s i}+h_{i}\right)
\end{array}
$$

where $k$ is the thermal conductivity $\left(\mathrm{W} \mathrm{m}^{-1}{ }^{\circ} \mathrm{C}^{-1}\right), \alpha$ is the albedo of snow for the solar radiation, $R_{I}\left(\mathrm{~W} \mathrm{~m}^{-2}\right), \lambda$ is the attenuation coefficient $\left(\mathrm{m}^{-1}\right)$ for the solar radiation, and $h$ is the thickness (m). The parameters with the subscripts, $s$, si and $i$ present those for snow, snow ice and candle ice, respectively. In Equations (2) - (4), the heat flux, $Q$, is expressed by the sum of the heat conduction and transmitted solar radiation.

The net heat input, $Q_{s t}$, at the snow surface $(z=0)$ is calculated by considering the following heat budget:

$$
R_{n}=Q_{H}+Q_{L}+Q_{s t}
$$

where $R_{n}$ is the net radiation, $Q_{H}$ is the sensible heat flux, $Q_{L}$ is the latent heat flux, and $Q_{s t}$ is the temporal change of heat storage below the snow surface. Here, $Q_{L}$ is neglected, since the sublimation at the snow surface is considered to be negligibly small. The net radiation, $R_{n}$, was estimated by the empirical equations, (7) and (8), of Penman (1949):

$$
\begin{aligned}
& R_{n}=(1-\alpha) R_{I}+R_{B} \\
& R_{I}=R_{A}(0.18+0.55 n / N) \\
& R_{B}=\sigma T_{a}^{4}\left(0.078 \sqrt{e_{a}}-0.56\right) \cdot(0.1+0.9 n / N)
\end{aligned}
$$

where $R_{B}$ is the net longwave radiation, $R_{A}$ is the potential solar radiation, $n$ is the actual daylight length (h), $N$ is the potential daylight length (h), $T_{a}$ and $e_{a}$ are the air temperature (K) and the vapor pressure (hPa) at $2 \mathrm{~m}$ above the snow surface, and $\sigma$ is the Stefan-Boltzmann constant $\left(=5.67 \times 10^{-8} \mathrm{~W} \mathrm{~m}^{-2} \mathrm{~K}^{-4}\right)$. The potential solar radiation, $R_{A}$, was calculated by the following equation: 


$$
R_{A}=\frac{\tau I_{o}}{\pi r^{2}}\left(\omega_{0} \sin \phi \sin \delta+\cos \phi \cos \delta \sin \omega_{0}\right)
$$

where $I_{\mathrm{o}}$ is the solar constant $\left(=1,367 \mathrm{~W} \mathrm{~m}^{-2}\right), \tau$ is the day length, $\omega$ is the time angle, $r$ is the ratio of the geocentric distance between the sun and the earth to its annually mean distance, $\varphi$ is the latitude, and $\delta$ is the declination of the sun. The time angle, $\omega$, is $-\omega_{0}$ and $+\omega_{0}$ at the sunrise and sunset, respectively, which are given by the following:

$$
\omega_{0}=\cos ^{-1}(-\tan \varphi \tan \delta)
$$

The sensible heat flux, $Q_{H}$, was numerically obtained by the bulk method of heat transfer:

$$
Q_{H}=\rho_{a} c_{p} C_{H} u\left(T_{0}-T_{a}\right)
$$

where $C_{H}$ is the dimensionless bulk transfer coefficient of sensible heat at $2 \mathrm{~m}$ above the snow surface, $u$ is the wind speed (m) at $2 \mathrm{~m}$ above the snow surface, $c_{p}$ is the specific heat of air $\left(\mathrm{J} \mathrm{kg}^{-1}{ }^{\circ} \mathrm{C}^{-1}\right), \rho_{a}$ is the air density $(\mathrm{kg}$ $\left.\mathrm{m}^{-3}\right)$, and $T_{0}$ is the temperature $\left({ }^{\circ} \mathrm{C}\right)$ at the snow surface.

Basic equations for the simulation of ice thickness

The temporal variation in thickness of candle ice is calculated by the heat budget at the boundary between

candle ice and lake water:

$$
\rho_{i} L_{i} \frac{d h_{i}}{d t}=\left[\left(-\rho_{w} c_{w} K \frac{d T_{w}(z)}{d z}\right)-\left(-k_{i} \frac{d T_{i}(z)}{d z}\right)\right]_{z=h_{S}+h_{S i}+h_{i}}
$$

where $L_{i}$ is the heat of fusion $\left(=3.34 \times 10^{5} \mathrm{~J} \mathrm{~kg}^{-1}\right), K$ is the thermal diffusivity of water $\left(\mathrm{m}^{2} \mathrm{~s}^{-1}\right), c_{w}$ and $\rho_{w}$ is the specific heat and density of water, and $T_{w}$ is the water temperature $\left({ }^{\circ} \mathrm{C}\right) . K$ was assumed to be equal to the molecular diffusivity $\left(=1.33 \times 10^{-7} \mathrm{~m}^{2} \mathrm{~s}^{-1}\right)$, since the lake water is very stagnant by the overlying snow and ice and 
non-influent and effluent rivers (Fig. 1). The water temperature record at $0.1 \mathrm{~m}$ below the candle-ice base exhibited a nearly constant of $0.5^{\circ} \mathrm{C}$ (Fig. 6). Hence, the heat flux from lake water to candle ice (the first term on the right side of Equation (12)) was supposed to be constant $\left(=2.81 \mathrm{~W} \mathrm{~m}^{-2}\right)$.

Similarly, the growth of snow ice is calculated by the heat budget at the boundary between snow ice and lake

water:

$$
\rho_{s i} L_{s i} \frac{d h_{s i}}{d t}=\left[\left(-\rho_{w} c_{w} K \frac{d T_{w}(z)}{d z}\right)-\left(-k_{s i} \frac{d T_{s i}(z)}{d z}\right)\right]_{z=h_{s}+h_{s i}}
$$

Here, $L_{s i}$ was assumed to be equal to $L_{i}$.

Methods for calculation

method with the grid size, $\Delta z=0.01 \mathrm{~m}$, and the time step, $\Delta t=1 \mathrm{sec}$ for the calculation convergence. The state of snow slush on 23 January 1995 was set to be at $0^{\circ} \mathrm{C}$ as the initial condition of Equation (1) (Fig. 2). The calculation for the snow ice growth by Equation (13) was continued, until the ice thickness was $0.04 \mathrm{~m}$, which corresponds to that of snow ice in the ice ridge observed (Fig. 4). The snow temperature during snowfall was assumed to be equal to the air temperature.

The albedo, $\alpha$, in Equations (2)-(4) and (6) was supposed to be 0.89 at the sun's elevation of $10^{\circ}$ or less, 0.85 at more than $10^{\circ}$ and $20^{\circ}$ or less, and 0.81 at more than $20^{\circ}$ (Carroll and Fitch 1981). The specific heat, density and thermal conductivity of snow, snow ice, and candle ice were set as in Table 1 . The densities, $\rho_{s i}$ and $\rho_{i}$, were measured at point F600 (Fig. 3), and the thermal conductivities, $k_{s i}$ and $k_{i}$, were obtained in laboratory by the 
thermal probe method. As a result, the values of the thermal conductivity were reasonable to those of Schwerdtfeger (1963). For the attenuation coefficients, $\lambda_{s}, \lambda_{s i}$ and $\lambda_{i}$, in equations (2) to (4), the values of Rogers et al. (1995) were adopted.

The air temperature, $T_{a}$, in Equations (8) and (11) was given as that at point F600 by using the linearity (correlation coefficient, $r=0.959$ ) between the air temperature at point F600 and that at point A (Fig. 1). The potential daylight length, $N$, was obtained at $1 \mathrm{hr}$ intervals, using Equation (10). The hourly data of the actual daylight length, $n$, and wind speed, $u$, were supplied by the weather station $6.4 \mathrm{~km}$ southwest of the lake. The nocturnal values of $n / N$ in Equation (8) were replaced by the cloudiness at the Muroran-city weather station. The snow depth above the covered ice was given every time step on the basis of the snowfall data in Noboribetsu-city.

Simulated results and their comparison with observations

Figure 7 shows a comparison between simulated and observed ice temperatures at point F600 for 3 to 5

March 1995. The simulated temperature variations at the snow-ice surface and $0.05 \mathrm{~m}$ depth are relatively reasonable to the observed ones, though, on the whole, the simulated variations are smaller in amplitude than the observed ones. The observed temperatures at depths of $0 \mathrm{~m}, 0.1 \mathrm{~m}$ and $0.15 \mathrm{~m}$ increased to $0{ }^{\circ} \mathrm{C}$ on 3 or 4 March, probably due to the ooze up of lake water through cracks. Thereafter, the simulated results at the depths are not agreeable to the observed ones. In Figure 8, the simulated, vertical profile (white circles) of ice temperature at 18:00h, 3 March (before the $0^{\circ} \mathrm{C}$ temperatures) explains well the observed plots at near the start of the observation, when all the ice temperatures were below $0^{\circ} \mathrm{C}$. 
January to $00: 00 \mathrm{~h}, 6$ February. It is noted that the temperature at the snow ice surface abruptly decreases on the early morning of 2 February. The great decrease probably made the ice contraction and many cracks on the covered ice as in Figure 2, and produced the dumping of ice blocks on the lakeshore (Fig. 5).

Figure 10 shows simulated, temporal variations of the ice thickness under the given snow depths for 00:00h, 24 January to 00:00h, 6 March at point F600, and the comparison with the observed ice thickness at points F2, F600 and F1200 for 3 to 5 March (Fig. 3). The simulated, total ice thickness is very reasonable to the observed one, though the simulated thickness (ca. $0.04 \mathrm{~m}$ ) of snow ice is somewhat underestimated. The snow slush, formed on 23 January by a large snowfall, starts freezing from the lake surface, and all is frozen into snow ice on 26 January. Thereafter, the candle ice continues growing, but the rate of the growth decreases by ice and candle ice, respectively (Fig. 5). In the simulation, this thickness for the candle ice appears on 2 February, and then the candle ice grows at the rate of $0.02 \mathrm{~m}$ per day. Hence, it is suggested that the covered ice started forming the ice-ridge line on 2 February and thrust up greatly on 3 February. After the formation of the ice ridge line on 2 February, the transparent ice was made at $0.02 \mathrm{~m}$ per day in thickness at the open water surface between the cracks. The ice-ridge line is thus judged to have built up by the thermal contraction and expansion of ice, due to the daily cooling and warming on 2 and 3 February (Fig. 2).

\section{Conclusions and future works}

The ice-ridge line built up in the deep Lake Kuttara, Japan in the ice-covered season of 1995. In order to 
the covered ice were measured, and the meteorology and the interior temperature of the ice were monitored. The covered ice and the ice ridge, which were covered by snow, commonly consisted of whitish snow ice and transparent candle ice. The structural condition of the ice blocks on or near the lakeshore was specified in connection with a decrease in lake water level in the ice-covered season. By using the decreasing rate, $5.2 \mathrm{~mm}$

5 day $^{-1}$, of the water level, the detachment and dumping of the lake-ice blocks on the lakeshore were judged to have occurred on 2 February. The detachment and dumping are probably effective to suppress the horizontal movement of the lake covered ice by thermal expansion. The numerical simulation for the temporal variations of ice temperature and ice thickness was carried out by applying the one-dimensional, unsteady three-layer model. The simulated results are reasonable to the observations, and hence, the formation of the ice-ridge line was 10 temporally traced; the ice-ridge line started to form on 2 February and was built up on 3 February, due to the daily thermal contraction and expansion of ice. The mechanical formation processes of the ice-ridge line are not clarified in this paper. The field measurements by strain gauges set in lake ice and the laboratory experiment for mechanical properties of lake ice should be added.

Acknowledgements We are greatly indebted to late Emeritus Professors, Kinshiro Nakao and Koichi Urakami, Hokkaido University, for their invaluable advice in our field survey and simulation. We also express our gratitude to some staffs of the Institute of Low Temperature Science, Hokkaido University, for their welcome offer of the use of a low-temperature laboratory. Ms. Naoko Mayeda, a curator of the Bear Museum, kindly gave us much information on the ice-covered conditions of Lake Kuttara. 


\section{References}

Boehrer B, Fukuyama R, Chikita K (2008) Stratification in very deep, purely thermally stratified lakes. Geophysical Research Letters 35: L16405, doi:10.1029/2008GL034519.

Carroll JJ, Fitch BW (1981) Effects of solar elevation and cloudiness on snow albedo at the South Pole. Journal of Geophysical Research 86: 5271-5276.

Chikita K, Hosogaya Y, Natsume S (1993) The characteristics of internal waves in a caldera lake introduced from field measurements: Lake Kuttara, Hokkaido. The Japanese Journal of Limnology 54: 213-224.

Chikita K, Sakata K, Hino S (1995) Transportation of suspended sediment slowly settling in a caldera lake. The Japanese Journal of Limnology 56: 245-257. Dynamic behaviors of anoxic water in a coastal lagoon, Lake Harutori, Kushiro, Hokkaido. Memoirs of the Kushiro City Museum, No. 22, 1-8.

Ishikawa N, Kobayashi S, Okitaya E (1979) A microclimatological research in Lake Kuttara, Hokkaido. Journal of Low Temperature Science 38: 121-127.

Kozeki M, Yoshida Z (1972) Vertical distribution of water temperature in Lakes Shikotsu and Kuttara, Hokkaido. Low Temperature Science, Ser. A, Physical Sciences, 29: 1-14.

Nakamura K, Toyama Y, Nishio F, Tokairin A (1998) A study on the thermal ice ridge in Lake Kussharo by satellite images. Snow \& Ice in Hokkaido 17: 54-57.

Nakao K, Ohtsuki S, Tanoue R, Naruse R (1967) Groundwater leakage from Lake Kuttara, Hokkaido. 
Penman HL (1949) A general survey of meteorology in agriculture and an account of the physics of irrigation control. Quarterly Journal of the Royal Meteorological Society 75: 293-302.

Pivovarov AA (1973) Thermal conditions in freezing lakes and rivers. John Wiley \& Sons, New York, 136pp..

Rogers CK, Lawrence GA, Hamblin PF (1995) Observations and numerical simulation of a shallow ice-covered midlatitude lake. Limnology \& Oceanography 40: 374-385.

Schwerdtfeger P (1963) The thermal properties of sea ice. Journal of Glaciology 4: 789-807.

Yoshimura S (1937) Limnology. Sanseido, Tokyo, 520pp. 


\section{Figure Legend}

Fig. 1 Location of Lake Kuttara Hokkaido, Japan and observation points. (A) Lake bathymetry and surrounding topography. (B) Location of observation points and lines, the ice-ridge line (thick wedge line) and fractures (two thick solid lines) on the covered ice.

5 Fig. 2 Air temperature at point A ( $\mathbf{d a i l y}$ maximum, odaily mean, $\boldsymbol{\Delta}$ daily minimum) and daily precipitation at the weather station $5 \mathrm{~km}$ from Lake Kuttara.

Fig. 3 Thickness (m) of snow, snow ice and candle ice measured at point F2, point F600 and point F1200. The density of snow ice and candle ice was also measured at point F600.

Fig. 4 Schematic of the structure of ice ridge at point $\mathrm{C}$.

Fig. 5 Schematic of the tectonics of covered-ice blocks on or near the lakeshore at point M. Lake water level was measured at points $\mathrm{N}$ and $\mathrm{P}$.

Fig. 6 Time series of (A) wind velocity, (B) air temperature, and (C) water and ice temperatures at point F600.

Fig. 7 Simulated, time series of ice temperatures (solid lines) and its comparison with the observed ones (dotted lines).

Fig. 8 Simulated, vertical profile of ice temperatures (solid line with white circles) and its comparison with the observation (black stars) at 18:00h, 3 March 1995.

Fig. 9 Simulated, time series of ice temperatures at the snow surface, $0.05 \mathrm{~m}$ depth and $0.10 \mathrm{~m}$ depth of point F600.

Fig. 10 Simulated, temporal variations of the ice thickness, and the comparison with the observation (black circles) 
Table 1 Values of parameters used for simulations.

\begin{tabular}{llcc}
\hline \hline & snow & snowice & candle ice \\
\hline density, $\rho\left(\mathrm{kg} \mathrm{m}^{-3}\right)$ & 150 & 907 & 917 \\
\hline specific heat, $c\left(\mathrm{~kJ} \mathrm{~kg}^{-1}{ }^{\circ} \mathrm{C}^{-1}\right)$ & 3.97 & 2.12 & 2.10 \\
\hline thermal conductivity, $k\left(\mathrm{~W} \mathrm{~m}^{-1}{ }^{\circ} \mathrm{C}^{-1}\right)$ & 0.110 & 2.05 & 2.10 \\
\hline attenuation coefficient, $\lambda\left(\mathrm{m}^{-1}\right)$ & 6.00 & 3.75 & 1.50 \\
\hline
\end{tabular}




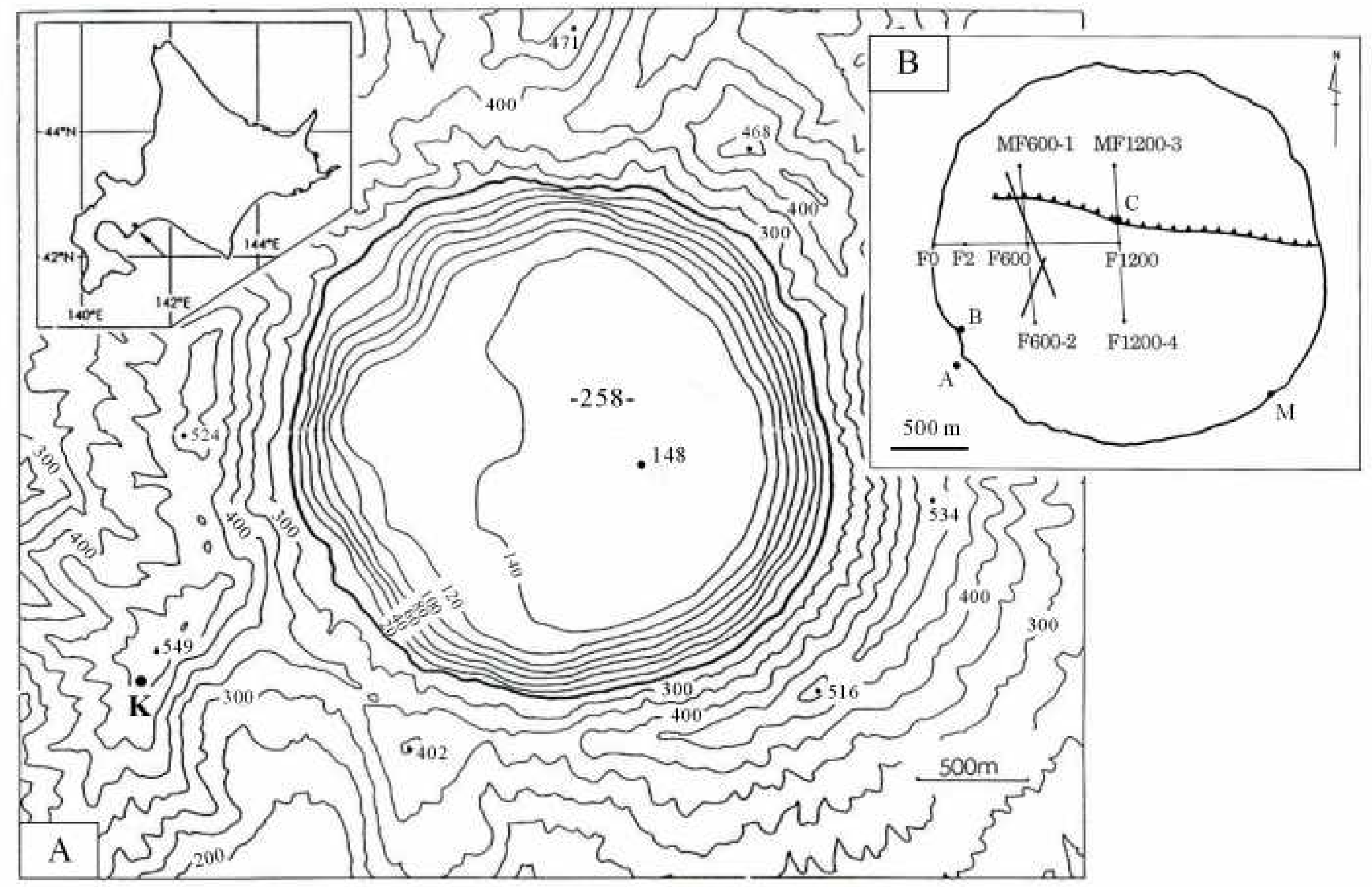

Figure 1. Location of Lake Kuttara Hokkaido, Japan and observation points. (A) Lake bathymetry and surrounding topography. (B) Location of observation points, the iceridge line ( $\iota$ ) and cracks (two thick solid lines) on the covered ice. 


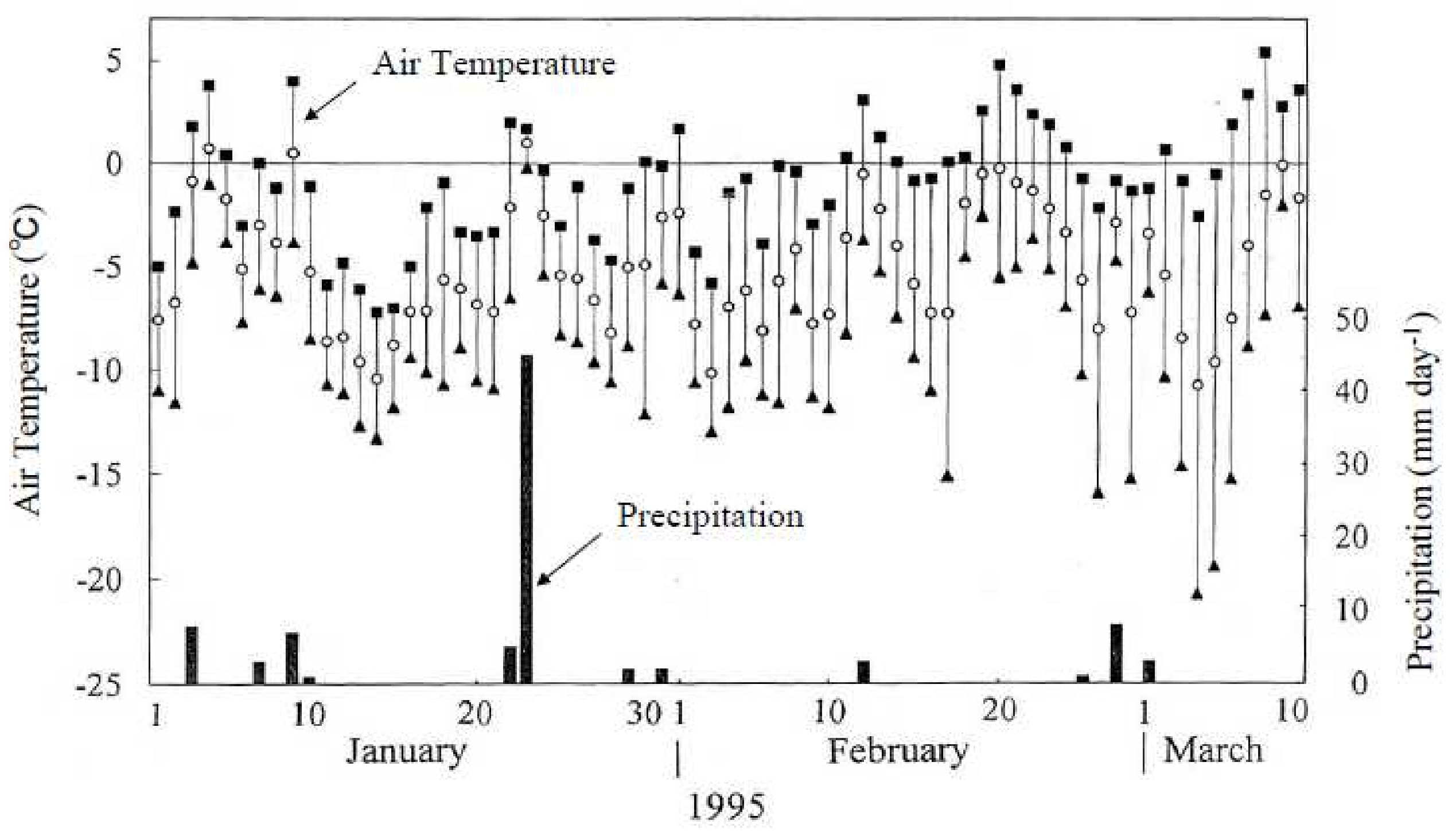

Figure 2. Air temperature at point A ( daily maximum, odaily mean, $\mathbf{\Lambda}$ daily minimum) and daily precipitation at the weather station $5 \mathrm{~km}$ from Lake Kuttara. 


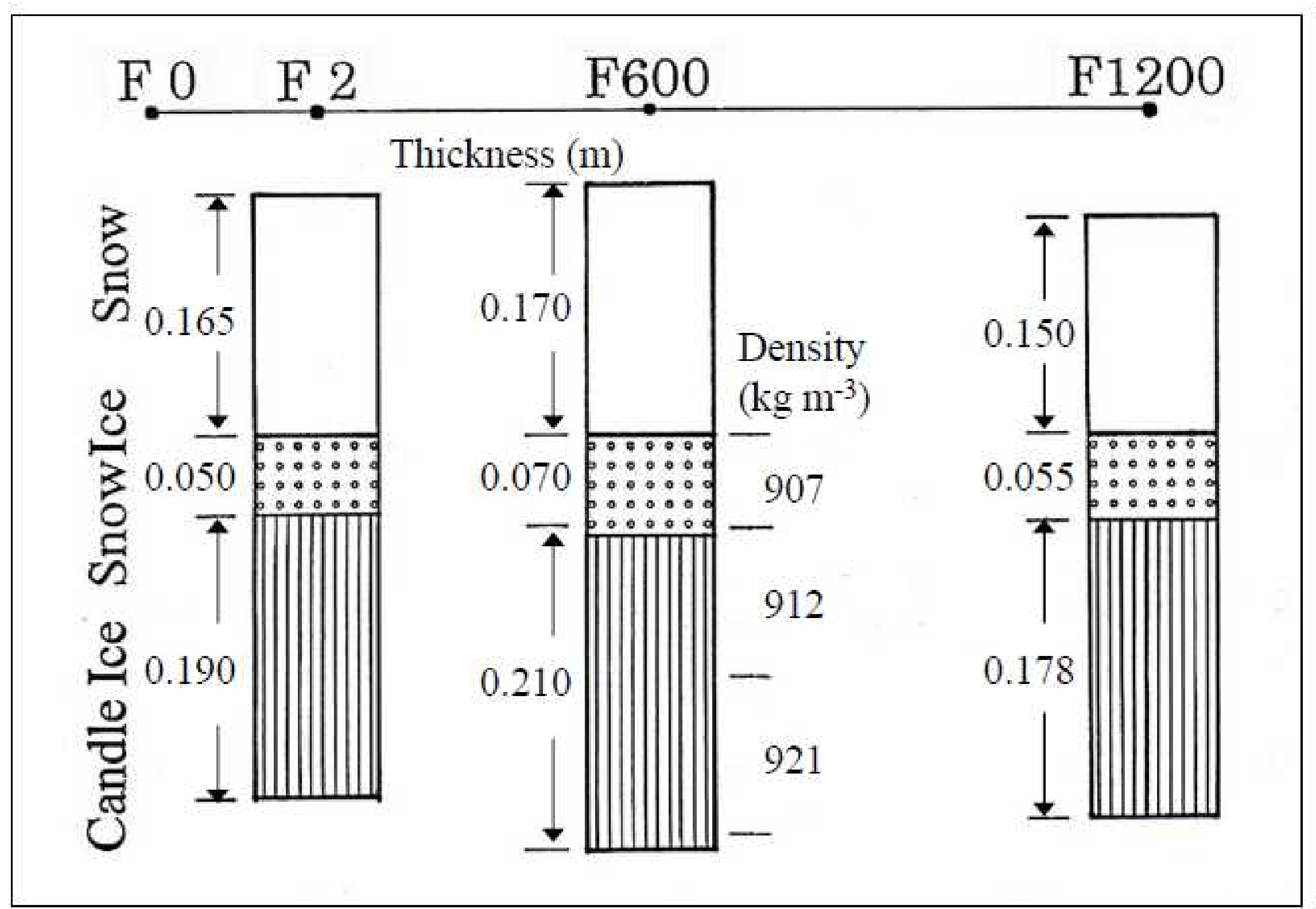

Figure 3. Thickness (m) of snow, snow ice and candle ice measured at point F2, point F600 and point F1200. The density of snow ice and candle ice was also measured at point F600. 


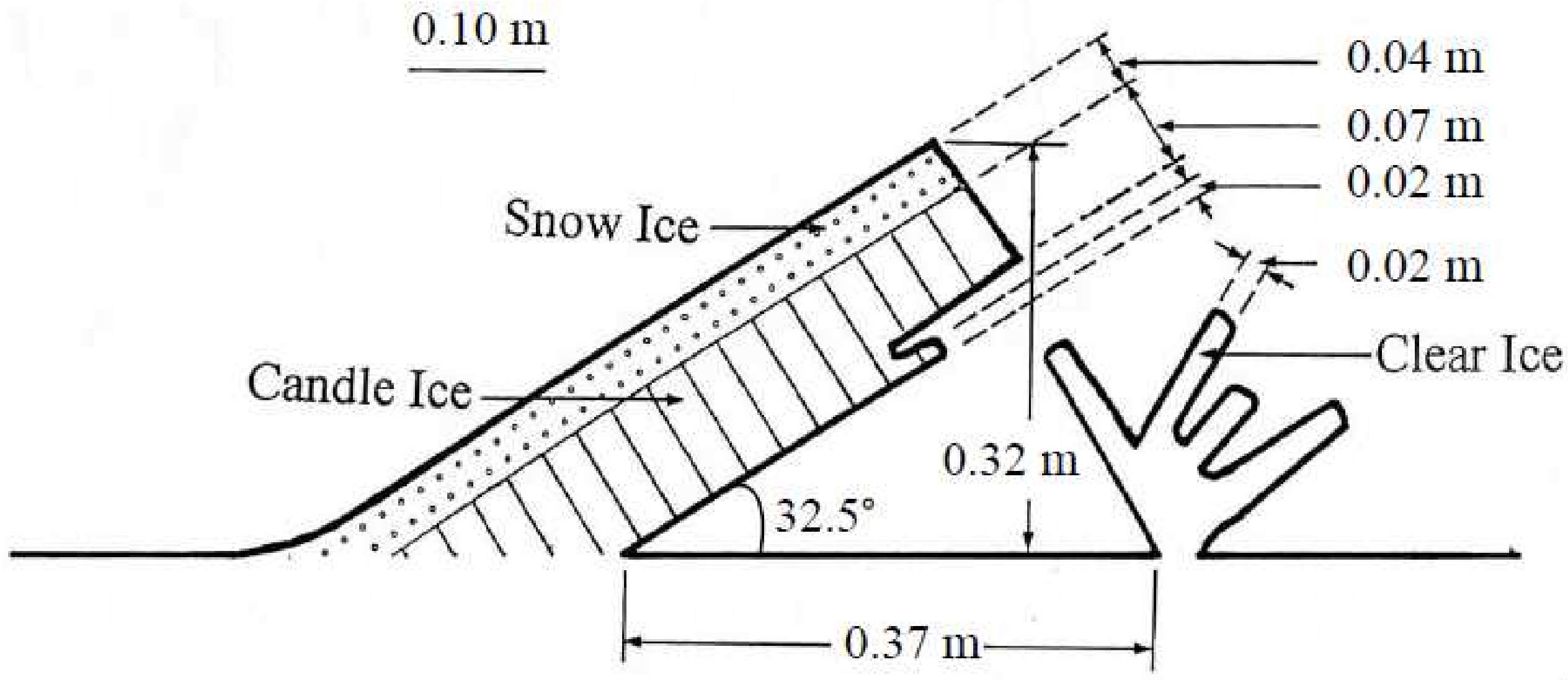

Figure 4. Schematic of the structure of ice ridge at point $C$. 


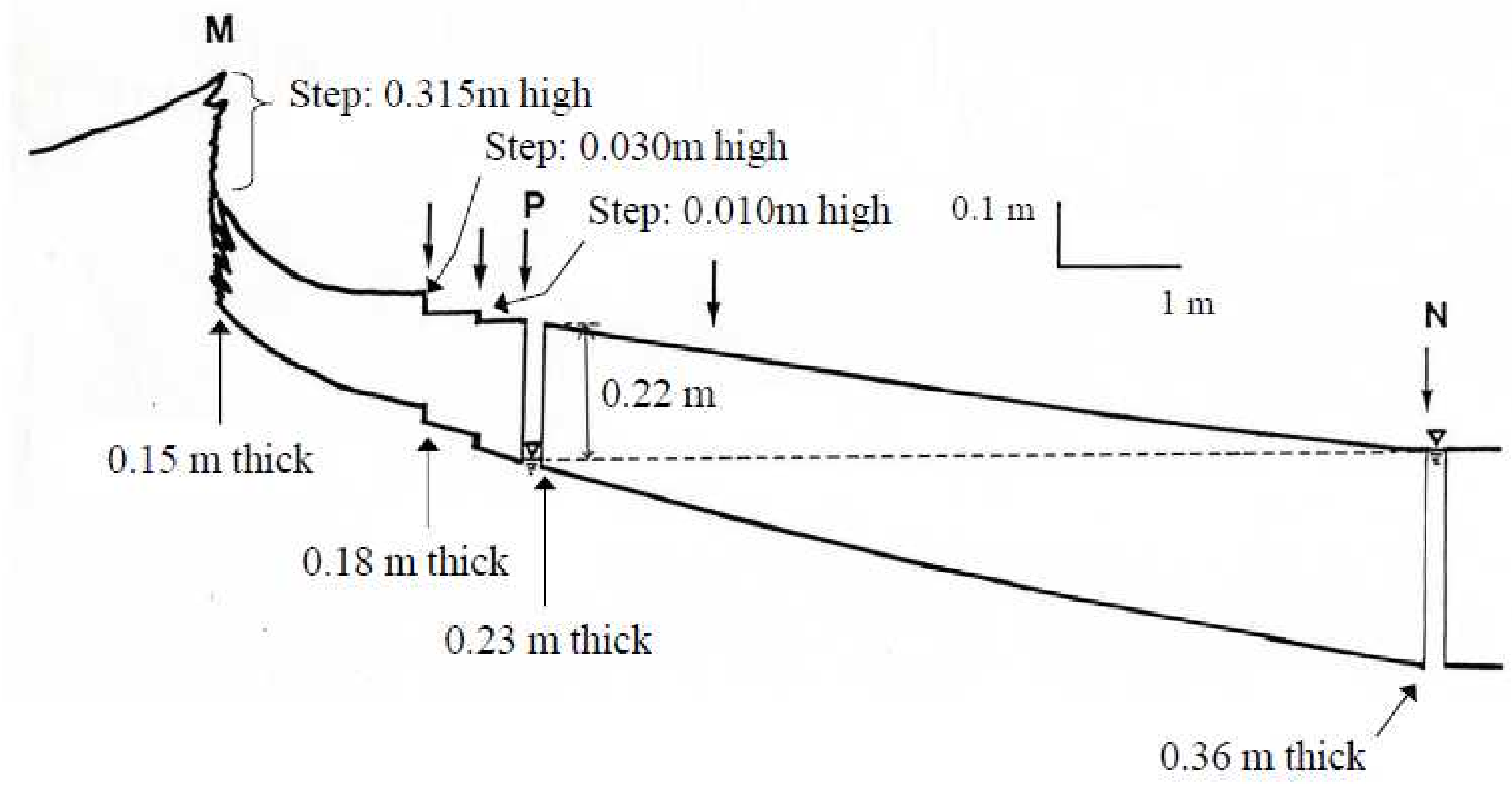

Figure 5. Schematic of the tectonics of covered-ice blocks on or near the lakeshore at point M. Lake water level was measured at points $\mathrm{N}$ and $\mathrm{P}$. 


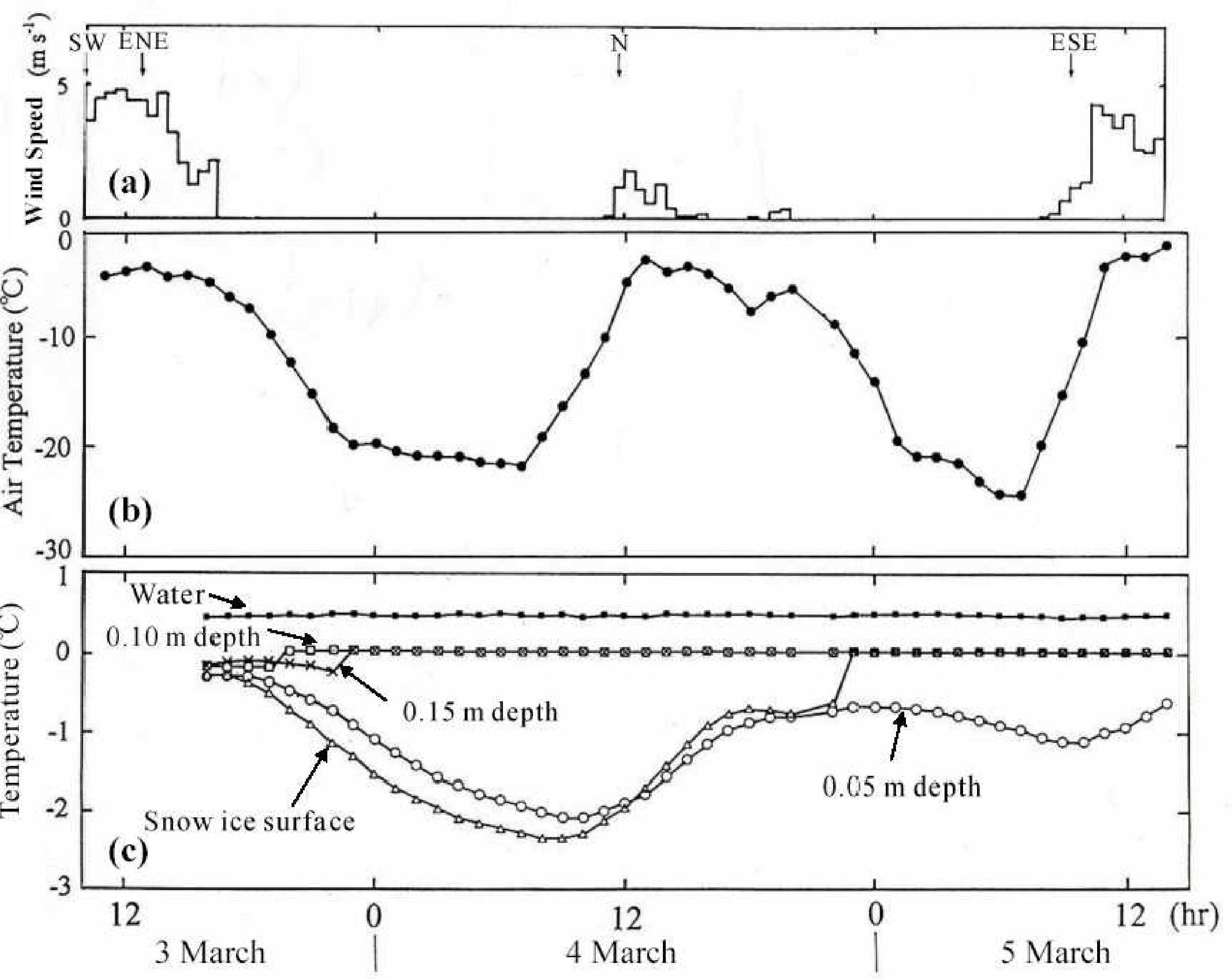




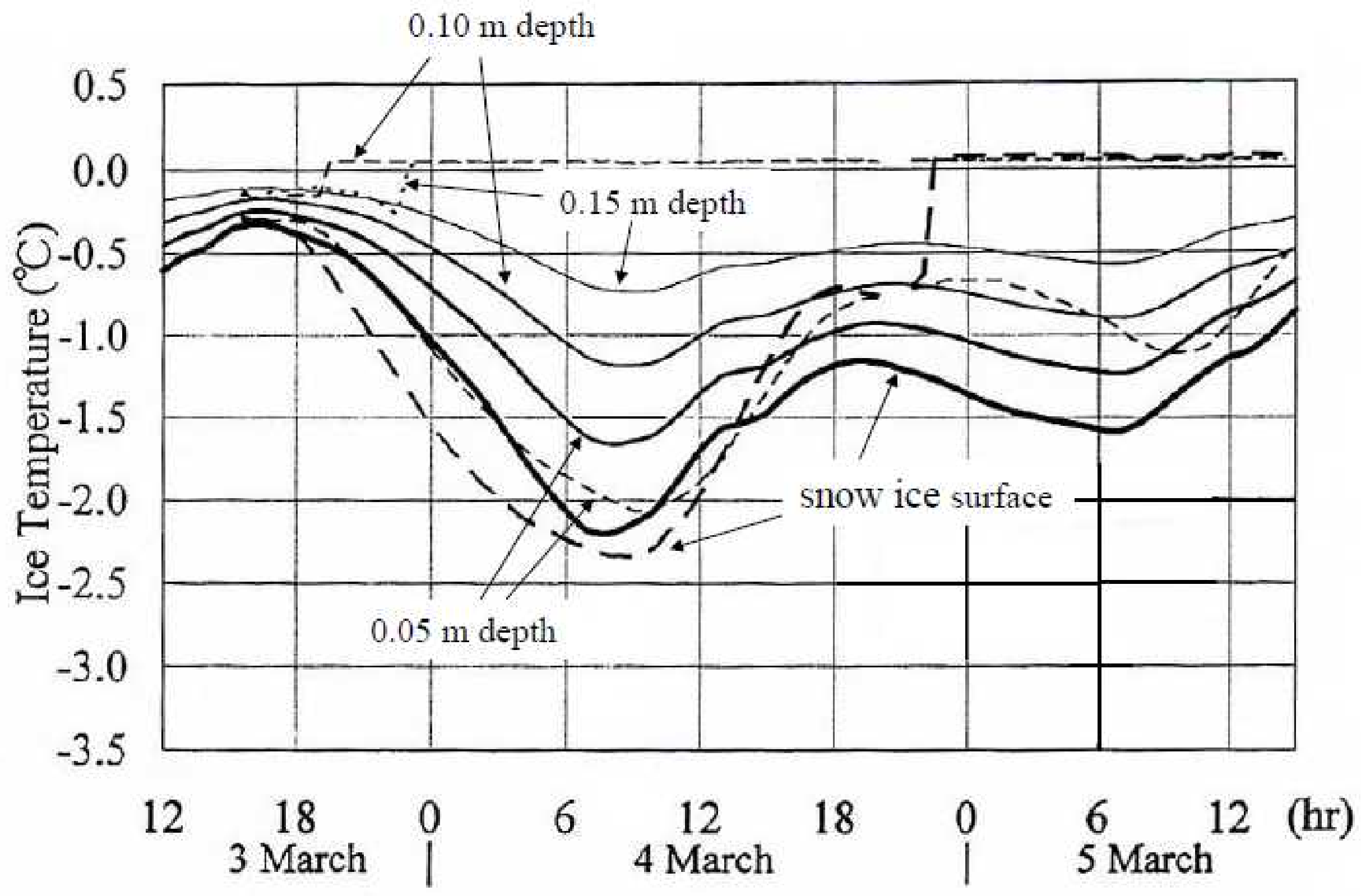

Figure 7. Simulated, time series of ice temperatures (solid lines) and its comparison with the observed ones (dotted lines). 


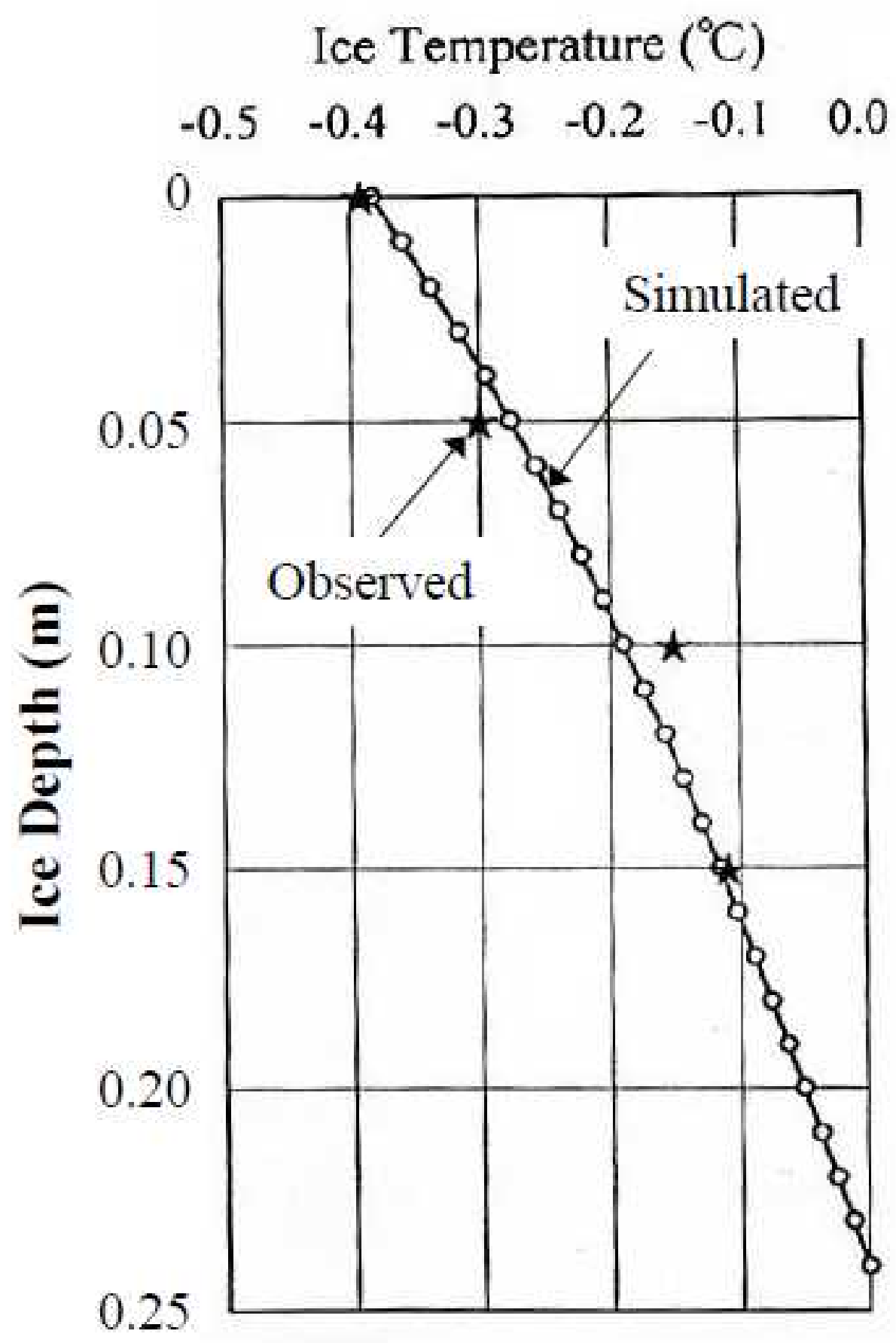

Figure 8. Simulated, vertical profile of ice temperatures (solid line with white circles) and its comparison with the observation (black stars) at 18:00h, 3 March 1995. 


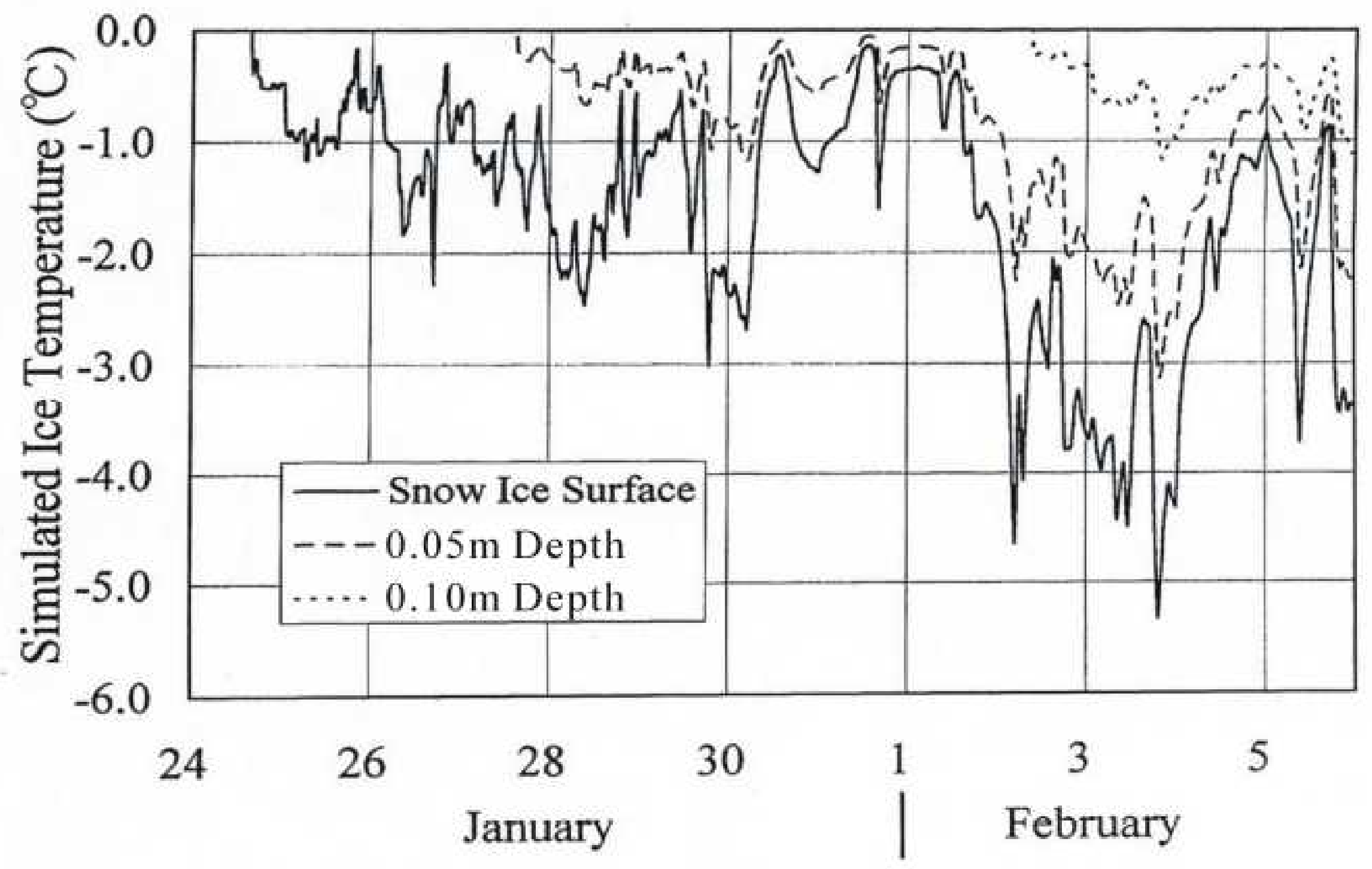

Figure 9. Simulated, time series of ice temperatures at the snow surface, $0.05 \mathrm{~m}$ depth and $0.10 \mathrm{~m}$ depth of point $\mathrm{F} 600$. 


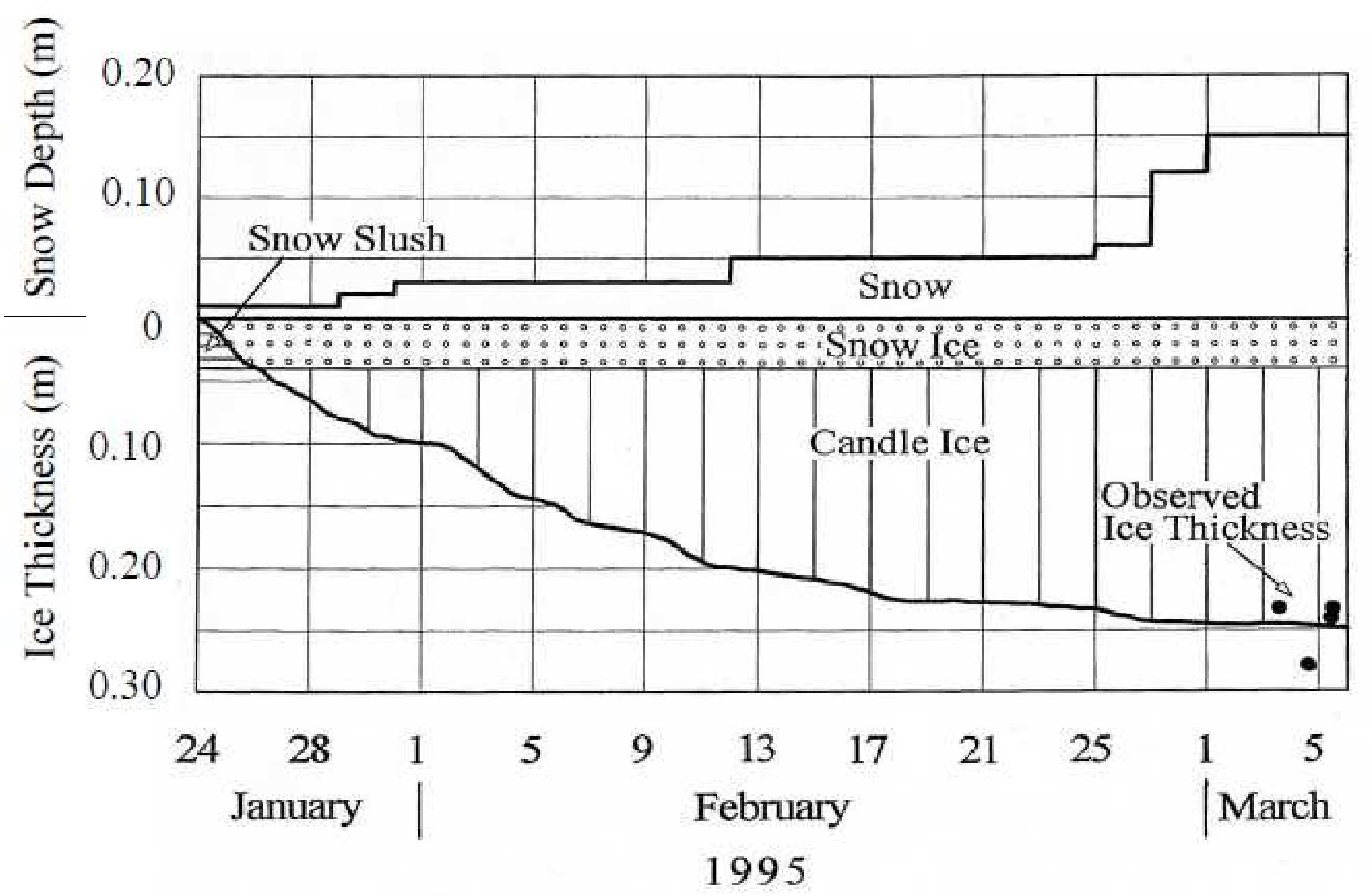

Figure 10. Simulated, temporal variations of the ice thickness, and the comparison with the observation (black circles). 